\title{
Verslaggeving van toegelaten instellingen volkshuisvesting
}

\section{Ernst-Jan Jungheim en Lianne Suurland}

SAMENVATTING Dit artikel beschrijft de uitkomsten van het onderzoek naar de wijze waarop woningcorporaties de wijzigingen in RJ 645 met betrekking tot de waardering en resultaatbepaling van vastgoed hebben verwerkt in de jaarrekening over 2012. Uit het onderzoek blijkt dat de in 2012 gekozen waarderingsgrondslag voor het sociaal en commercieel vastgoed belangrijke invloed heeft op de omvang van het eigen vermogen primo 2012 en op het resultaat over 2012. Verder blijkt dat woningcorporaties de toelichting van de bedrijfswaarde en de marktwaarde van het vastgoed kunnen verbeteren. Tot slot constateren we dat woningcorporaties verschillend zijn omgegaan met het al dan niet inrekenen van de verhuurderheffing en de inkomensafhankelijke huurverhoging in de bedrijfswaarde hetgeen de vergelijkbaarheid tussen woningcorporaties niet ten goede komt.

RELEVANTIE VOOR DE PRAKTIJK De wijzigingen met betrekking tot de waardering en resultaatbepaling van onroerende zaken in exploitatie in RJ 645 Toegelaten instellingen volkshuisvesting hebben belangrijke invloed op de jaarrekening van woningcorporaties. In dit artikel zijn bevindingen en aanbevelingen opgenomen op basis van empirisch onderzoek over de classificatie, waardering en toelichting van onroerende zaken in exploitatie in de jaarrekening. Opstellers, controleurs en toezichthouders kunnen de bevindingen van het onderzoek gebruiken om de informatieverstrekking in de jaarrekening van woningcorporaties te verbeteren.

\section{Inleiding}

Toegelaten instellingen volkshuisvesting (hierna: woningcorporaties) hebben te maken met ingrijpende wijzigingen in de voorschriften voor de jaarverslaggeving over 2012. Ingaande 2012 is het herziene hoofdstuk 645 Toegelaten instellingen volkshuisvesting van de Richtlijnen voor de jaarverslaggeving (herziene RJ 645) van toepassing. In dit hoofdstuk is een aantal belangrijke wijzigingen opgenomen ten aanzien van de waardering en resultaatbepaling van vastgoed in exploitatie. In dit artikel beschrijven we de uitkomsten van het onderzoek naar de wijze waarop woningcorporaties de wijzigingen in RJ 645 hebben verwerkt in de jaarrekening over 2012. Wij beperken ons tot de meest ingrij- pende wijzigingen te weten de classificatie, waardering, presentatie en toelichting van vastgoed in exploitatie. Daarnaast hebben we specifiek onderzoek gedaan naar de wijze waarop woningcorporaties de verhuurderheffing (zie paragraaf 6.3.1) hebben ingerekend bij de bepaling van de bedrijfswaarde.

Het artikel is als volgt opgebouwd. In paragraaf 2 wordt het verslaggevingskader voor woningcorporaties uiteengezet. Paragraaf 3 behandelt de opzet van het empirisch onderzoek en de selectie van de onderzoekspopulatie. In paragraaf 4 behandelen wij enkele kengetallen van de onderzochte woningcorporaties. In paragraaf 5 gaan wij in op de classificatie en kwalificatie van vastgoed en in paragraaf 6 op de waardering en toelichting van sociaal en commercieel vastgoed. In beide paragrafen behandelen wij per onderwerp de regelgeving, onze bevindingen en voorbeelden die wij als best practice beschouwen. In paragraaf 7 sluiten wij af met onze conclusies en aanbevelingen.

\section{Verslaggevingskader}

Woningcorporaties moeten op grond van artikel 26 van het Besluit beheer sociale huursector (BBSH) jaarlijks een jaarrekening, een jaarverslag en een volkshuisvestingsverslag opstellen. Ook moeten zij overige gegevens aan de jaarrekening en het jaarverslag toevoegen (art. 2:392 BW). De jaarrekening, het jaarverslag en de overige gegevens moeten worden opgemaakt in overeenstemming met Titel 9 Boek 2 BW, met uitzondering van de afdeling 1 'Algemene bepaling', afdeling 9 'Deskundigenonderzoek', afdeling 12 'Bepalingen omtrent rechtspersonen van onderscheiden aard', afdeling 14 'Bepalingen voor banken' en afdeling 15 'Bepalingen voor verzekeringsmaatschappijen'. De bepalingen uit Titel 9 Boek 2 BW die gezien hun inhoud niet voor stichtingen en verenigingen gelden, en enkele specifiek genoemde artikelen, zijn niet van toepassing. Zo is art. 2:390 BW inzake de herwaarderingsreserve niet van toepassing op woningcorporaties.

In de Richtlijnen voor de jaarverslaggeving is een afzonderlijk hoofdstuk opgenomen voor woningcorporaties: RJ 645 Toegelaten instellingen volkshuisvesting. RJ 645 
richt zich op onderwerpen die specifiek zijn voor woningcorporaties. De overige hoofdstukken van de Richtlijnen voor de jaarverslaggeving zijn ook van toepassing.

\section{Opzet empirisch onderzoek en selectie onder- zoekspopulatie}

Het onderzoek richt zich op jaarrekeningen 2012 van woningcorporaties. Per 31 december 2012 waren er 381 woningcorporaties in Nederland. De onderzoekspopulatie is bepaald op basis van de lijst van woningcorporaties op de website van het Centraal Fonds Volkshuisvesting (Centraal Fonds Volkshuisvesting, 2012). Deze lijst is geactualiseerd naar een lijst van woningcorporaties per 31 december 2012. Uit deze lijst is een steekproef getrokken van 50 woningcorporaties met meer dan 1.500 verhuureenheden. Voor het onderzoek zijn de woningcorporaties verdeeld in vijf verschillende klassen op basis van het aantal verhuureenheden. Uit elke klasse zijn aselect tien woningcorporaties geselecteerd. De opbouw van de steekproef is in tabel 1 weergegeven. De lijst met onderzochte woningcorporaties is opgenomen in bijlage 1 .

\section{Kengetallen onderzoekspopulatie}

In tabel 2 zijn enkele kengetallen weergegeven van de onderzochte woningcorporaties. Uit deze tabel blijkt dat de herziene RJ 645 bij alle categorieën woningcorporaties heeft geleid tot omvangrijke mutaties in het eigen vermogen primo boekjaar als gevolg van stelselwijziging. Bij woningcorporaties met meer dan 20.000 verhuureenheden heeft de herziene RJ 645 geleid tot een toename van het eigen vermogen primo 2012 als gevolg van stelselwijziging met gemiddeld

\section{Tabel 1 Opbouw onderzoekspopulatie empirisch onderzoek}

\begin{tabular}{|l|c|c|}
\hline Categorie & $\begin{array}{c}\text { Aantal } \\
\text { verhuureenheden }\end{array}$ & Aantal corporaties \\
\hline 1 & $1.500-5.000$ & 10 \\
\hline 2 & $5.000-10.000$ & 10 \\
\hline 3 & $10.000-15.000$ & 10 \\
\hline 4 & $15.000-20.000$ & 10 \\
\hline 5 & $20.000+$ & 10 \\
\hline
\end{tabular}

$130 \%$. Deze stijging wordt met name veroorzaakt doordat alle onderzochte corporaties met meer dan 20.000 verhuureenheden zijn overgegaan op het actuele-waardemodel voor de waardering van hun vastgoed in exploitatie (zie paragraaf 6.1.2). Bij de onderzochte woningcorporaties met minder dan 20.000 verhuureenheden is de stijging van het eigen vermogen primo 2012 minder groot. Gemiddeld genomen is het eigen vermogen van de onderzochte woningcorporaties primo 2012 als gevolg van stelselwijziging met $81 \%$ gestegen.

Het gemiddeld resultaat na belastingen van woningcorporaties die hun vastgoed volgens het kostprijsmodel waarderen is in 2012 licht negatief (gemiddeld $€ 0,3 \mathrm{mln}$.). Het gemiddeld resultaat van woningcorporaties die hun vastgoed volgens het actuele-waardemodel waarderen is daarentegen fors negatief (gemiddeld $€ 27 \mathrm{mln}$.).

\section{Tabel 2 Kengetallen van de onderzochte onderzoekspopulatie}

\begin{tabular}{|c|c|c|c|c|c|c|}
\hline Categorie & 1 & 2 & 3 & 4 & 5 & Totaal \\
\hline Gemiddeld aantal verhuureenheden & 3.038 & 7.343 & 12.347 & 16.871 & 36.948 & 15.309 \\
\hline Gemiddelde huuromzet $(x € 1.000)$ & 15.306 & 36.668 & 64.998 & 80.502 & 182.175 & 75.930 \\
\hline Gemiddeld resultaat na belastingen $(x € 1.000)$ & -803 & -416 & -17.290 & -18.082 & -66.693 & -20.657 \\
\hline Gemiddeld balanstotaal ultimo boekjaar (x€1.000) & 159.531 & 395.710 & 762.468 & 922.770 & 2.673 .918 & 982.879 \\
\hline $\begin{array}{l}\text { Gemiddeld eigen vermogen primo boekjaar } \\
\text { (na verwerking effect stelselwijziging) }(x € 1.000)\end{array}$ & 56.093 & 168.012 & 298.374 & 346.668 & 1.250 .056 & 746.261 \\
\hline $\begin{array}{l}\text { Gemiddeld eigen vermogen primo boekjaar } \\
\text { (voor verwerking effect stelselwijziging) }(x € 1.000)\end{array}$ & 33.800 & 91.337 & 213.221 & 185.228 & 556.291 & 411.390 \\
\hline Gemiddeld eigen vermogen ultimo boekjaar $(x € 1.000)$ & 55.376 & 178.829 & 311.487 & 338.504 & 1.227 .151 & 736.530 \\
\hline $\begin{array}{l}\text { Gemiddelde rechtstreekse mutatie op eigen vermogen primo } \\
\text { boekjaar als gevolg van stelselwijziging ( } x € 1.000)\end{array}$ & 22.293 & 76.675 & 85.153 & 161.440 & 693.765 & 334.870 \\
\hline $\begin{array}{l}\text { Gemiddelde mutatie eigen vermogen primo boekjaar als } \\
\text { gevolg van stelselwijziging / gemiddeld eigen vermogen primo } \\
\text { boekjaar voor stelselwijziging }\end{array}$ & $66 \%$ & $84 \%$ & $40 \%$ & $87 \%$ & $125 \%$ & $81 \%$ \\
\hline $\begin{array}{l}\text { Gemiddeld resultaat woningcorporaties die hun vastgoed } \\
\text { volgens het kostprijsmodel waarderen ( } x € 1.000)\end{array}$ & -1.882 & 4.268 & -1.453 & -2.220 & n.v.t. & -322 \\
\hline $\begin{array}{l}\text { Gemiddeld resultaat woningcorporaties die hun vastgoed } \\
\text { volgens het actuele-waardemodel waarderen }(x € 1.000)\end{array}$ & 276 & -3.539 & -24.078 & -40.644 & -66.693 & -26.936 \\
\hline
\end{tabular}




\section{Classificatie en kwalificatie vastgoed}

\subsection{Regelgeving}

Een belangrijke wijziging in RJ 645 is dat een woningcorporatie zijn bezit moet classificeren als sociaal dan wel als commercieel vastgoed. Met deze classificatie sluit de Raad voor de Jaarverslaggeving aan op de uitgangspunten zoals deze zijn opgenomen in de beschikking van de Europese Commissie aangaande staatssteun met betrekking tot toegelaten instellingen van 15 december 2009 (European Commission, 2009).

Volgens de beschikking is staatssteun aan woningcorporaties alleen toegestaan voor de activiteiten die aangemerkt kunnen worden als diensten van algemeen economisch belang. Dit vereist een administratieve scheiding tussen de niet-staatssteunactiviteiten (commerciële tak) en staatssteunactiviteiten (sociale tak) van de woningcorporaties. De beschikking van de Europese Commissie onderscheidt daarom twee soorten vastgoed: - vastgoed dienstbaar aan de diensten van algemeen economisch belang (DAEB);

- overig vastgoed.

Het DAEB-bezit betreft huurwoningen met een huurprijs beneden de sociale huurgrens (2012: € 664,66; 2013: € 681,02), maatschappelijk vastgoed en overig sociaal vastgoed. Maatschappelijk vastgoed is bedrijfsonroerend goed dat is verhuurd aan maatschappelijke organisaties, waaronder zorg-, welzijn-, onderwijs- en culturele instellingen en dienstverleners en tevens is vermeld op de bijlage bij de Beschikking van de Europese Commissie. Huurwoningen met een huurprijs boven de sociale huurgrens, bedrijfsonroerend goed en garages behoren tot het overige vastgoed.

De uitvoering van de beschikking van de Europese Commissie vraagt ten behoeve van het toezicht een gescheiden verantwoording over de exploitatie van het DAEB-vastgoed en het overig vastgoed in de jaarrekening. RJ 645 sluit aan bij de uitgangspunten zoals deze zijn opgenomen in de Beschikking van de Europese Commissie. Het DAEB-vastgoed wordt in RJ 645 aangeduid als 'sociaal vastgoed' en het overig vastgoed als 'commercieel vastgoed'.

Woningcorporaties dienen hun vastgoed volgens de herziene RJ 645 in te delen naar sociaal en commercieel vastgoed. Het sociaal vastgoed dient ten behoeve van de jaarrekening te worden gekwalificeerd als 'bedrijfsmiddel' of als 'vastgoedbelegging' (RJ 645.204). Dit geldt voor het sociaal vastgoed als geheel. Deze indeling dient te worden gebaseerd op het eigen beleid van de woningcorporatie (RJ 940):

- Sociaal vastgoed gekwalificeerd als bedrijfsmiddel: deze kwalificatie is van toepassing als de woningcor- poratie een beleid heeft gericht op het realiseren van de volkshuisvestelijke taken.

- Sociaal vastgoed gekwalificeerd als vastgoedbelegging: deze kwalificatie is van toepassing indien de woningcorporatie een beleid heeft gericht op het realiseren van een zo optimaal mogelijk rendement ${ }^{1}$. De kwalificatie van het sociaal vastgoed als bedrijfsmiddel of vastgoedbelegging is van belang in verband met de waardering van het sociaal vastgoed (zie paragraaf 6).

Woningcorporaties dienen in de toelichting van de jaarrekening informatie op te nemen over de wijze waarop de classificatie en kwalificatie van het sociaal en commercieel vastgoed heeft plaatsgevonden (RJ 645.503).

\subsection{Empirisch onderzoek}

Alle onderzochte woningcorporaties hebben het bezit ingedeeld in sociaal en commercieel vastgoed. Eén woningcorporatie (2\%) bezit geen commercieel vastgoed.

42 woningcorporaties (84\%) kwalificeren het sociaal vastgoed als bedrijfsmiddel en acht woningcorporaties (16\%) als vastgoedbelegging (zie tabel 3). Uit het onderzoek blijkt dat kwalificatie als bedrijfsmiddel het meest voorkomt bij de relatief kleinere woningcorporaties. Kwalificatie als vastgoedbelegging komt het meest voor bij de grotere woningcorporaties met meer dan 20.000 verhuureenheden.

\section{Tabel 3 Kwalificatie sociaal vastgoed}

\begin{tabular}{|l|c|c|}
\hline Categorie & Bedrifismiddel & Vastgoedoelegging \\
\hline $1.500-5.000$ & 10 & 0 \\
\hline $5.000-10.000$ & 9 & 1 \\
\hline $10.000-15.000$ & 9 & 1 \\
\hline $15.000-20.000$ & 9 & 1 \\
\hline $20.000+$ & 5 & 5 \\
\hline Totaal & $\mathbf{4 2}$ & $\mathbf{8}$ \\
\hline
\end{tabular}

48 woningcorporaties (96\%) vermelden in de toelichting op welke wijze de classificatie en kwalificatie van het sociaal en commercieel vastgoed heeft plaatsgevonden. Bij twee (4\%) woningcorporaties ontbreekt deze vermelding. In figuur 1 is een voorbeeld opgenomen van een toelichting op de classificatie en kwalificatie van het sociaal en commercieel vastgoed in de jaarrekening van Stichting Woonbron. 
Figuur 1 Best practice toelichting classificatie en kwalificatie sociaal en commercieel vastgoed. Stichting Woonbron, jaarrekening 2012, pp. 10-11

Met ingang van het boekjaar 2012 kwalificeert Woon bron haar sociaal vastgoed in haar verslaggeving, uitgaande van de bepalingen in RJ 213, als vastgoedbelegging waarbij waardering van het sociaal vastgoed plaatsvindt, uitgaande van de marktwaarde in verbuurde staat.

De kwalificatie van het sociaal vastgoed als vastgoedbelegging sluit het beste aan bij de binnen Woonbron gangbare praktijk, waarbij sprake is van een portefeuillestrategie, en actieve sturing op vastgoedwaarden plaatsvindt, teneinde optimale rendementen op het vastgoed te bereiken.

Met de in 2012 doorgevoerde stelselwijziging wordt het inzicht in de financiële rendementen van de vastgoedportefenille belangrijk verbeterd doordat de presentatie hiervan zichtbaar in de winst- en verliesrekening plaatsvindt en anderszins ook beter vergelijking met de prestaties van overige vastgoedbeleggers kan plaatsvinden. Daarnaast kan Woonbron als toegelaten instelling beter inzichtelijk maken op welke wijze de bedrijfsvoering in financiële zin verschilt van die van commerciële vastgoedbeleggers en wat aldus de vermogensopoffering is die het gevolg is van het feit dat Woonbron haar bezit ter beschikking stelt aan haar specifieke doelgroep. Woonbron hanteert in dit kader de maatschappelijke vermogensbenadering om inzicht te bieden in de samenstelling van haar vermogen.

\section{Waardering en toelichting van het vastgoed}

\subsection{Kostprijsmodel en actuele-waardemodel}

\subsubsection{Regelgeving}

De nieuwe indeling van het vastgoed volgens de herziene RJ 645 heeft ingrijpende gevolgen voor de waardering van het vastgoed in de jaarrekening. Dit is uiteengezet in figuur 2 (Deloitte, 2011).

Woningcorporaties hebben na de eerste waardering per categorie van onroerende zaken de keuze om deze te waarderen volgens het kostprijsmodel of het actuelewaardemodel (RJ 645.205). De uitwerking van het kostprijsmodel is voor alle onroerende zaken in exploitatie in beginsel gelijk. De uitwerking van het actuele-waardemodel is voor de verschillende categorieën vastgoed verschillend:

- Voor sociaal vastgoed gekwalificeerd als bedrijfsmiddel dient het actuele-waardemodel van RJ 212.403 te worden toegepast. Dit betekent dat sociaal vastgoed gekwalificeerd als bedrijfsmiddel wordt gewaardeerd tegen de vervangingswaarde dan wel de bedrijfswaarde, als deze lager is dan de vervangingswaarde. Bij woningcorporaties is de bedrijfswaarde van het sociaal vastgoed veelal lager dan de vervangingswaarde, waardoor woningcorporaties hun sociaal vastgoed bij toepassing van het actuele-waardemodel op bedrijfswaarde waarderen. Waardemutaties in de bedrijfswaarde

\section{Figuur 2 Overzicht waardering van onroerende zaken in exploitatie}

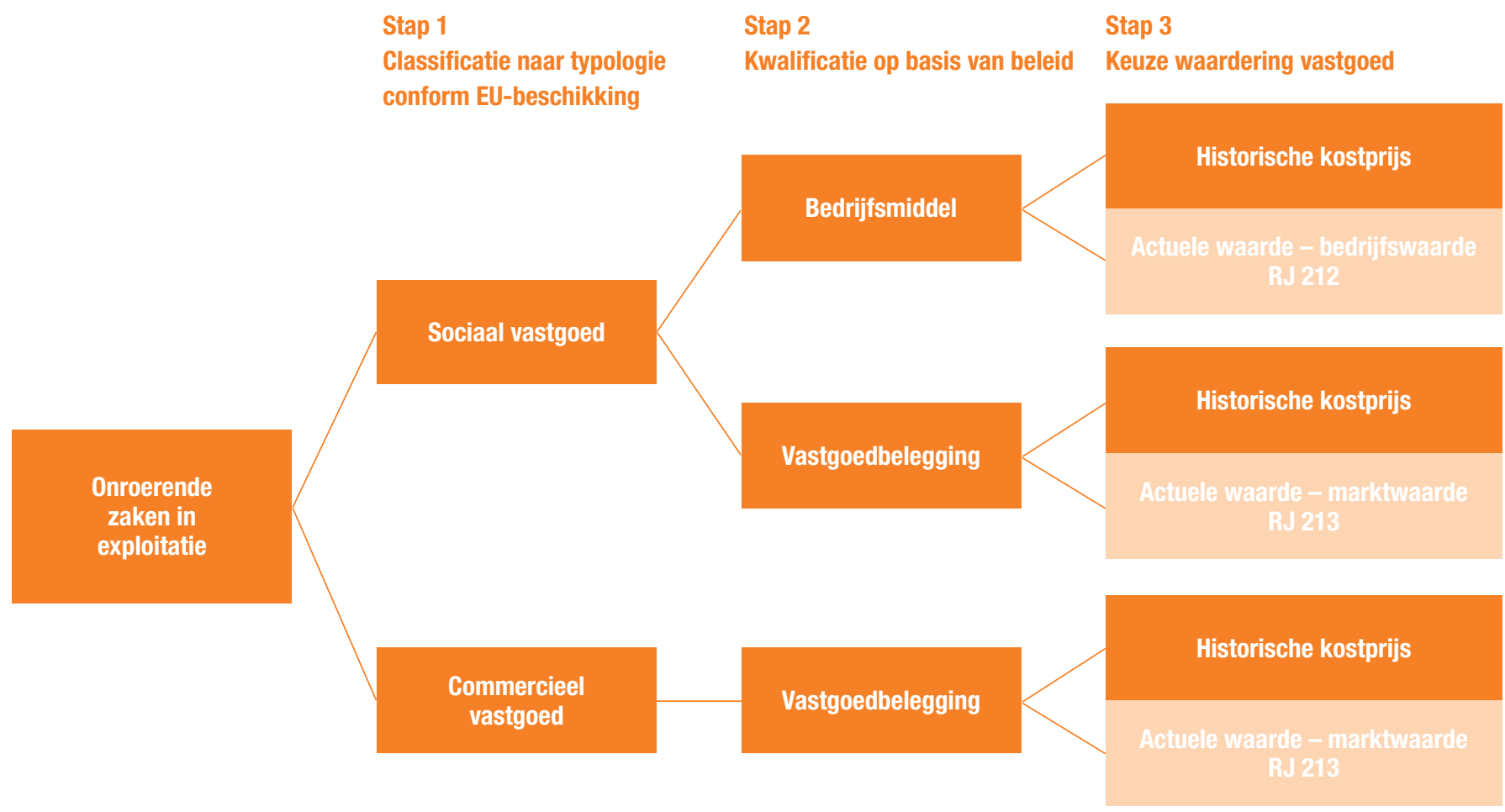


Tabel 4 Waarderingsgrondslag sociaal vastgoed

\begin{tabular}{|l|c|c|c|c|}
\hline Categorie & \multicolumn{2}{|c|}{ Bedriffsmiddel } & \multicolumn{2}{c|}{ Vastgoedloelegging } \\
\hline & Kostprijsmodel & Actuele-waardemodel (RJ 212) & Kostprijsmodel & Actuele-waardemodel (RJ 213) \\
\hline $1.500-5.000$ & 5 & 5 & 0 & 0 \\
\hline $5.000-10.000$ & 4 & 5 & 0 & 1 \\
\hline $10.000-15.000$ & 3 & 6 & 0 & 1 \\
\hline $15.000-20.000$ & 4 & 5 & 0 & 5 \\
\hline $20.000+$ & 0 & 5 & 0 & $\mathbf{0}$ \\
\hline Totaal & $\mathbf{1 6}$ & $\mathbf{2 6}$ & & $\mathbf{8}$ \\
\hline
\end{tabular}

moeten rechtstreeks in het eigen vermogen worden verwerkt.

- Voor sociaal vastgoed gekwalificeerd als vastgoedbelegging en voor commercieel vastgoed dient het actuele-waardemodel van RJ 213 Vastgoedbeleggingen te worden toegepast. Dit houdt in dat het vastgoed wordt gewaardeerd tegen marktwaarde. Waardemutaties in de marktwaarde moeten direct in de winsten-verliesrekening worden verwerkt.

Onder de 'oude' RJ 645 werd alle vastgoed bij waardering volgens het actuele-waardemodel gewaardeerd tegen bedrijfswaarde. Mutaties in de bedrijfswaarde werden direct in de winst-en-verliesrekening verwerkt. Kortom, in de herziene RJ 645 is het actuele-waardebegrip ten opzichte van de 'oude' RJ 645 aangescherpt en uitgebreid.

\subsubsection{Empirisch onderzoek}

Van de 42 woningcorporaties die hun sociaal vastgoed kwalificeren als bedrijfsmiddel passen 16 woningcorporaties $(38 \%)$ de waarderingsgrondslag historische kostprijs toe (zie tabel 4). De overige 26 woningcorporaties (62\%) passen het actuele-waardemodel toe en waarderen hun sociaal vastgoed op bedrijfswaarde. Alle woningcorporaties die hun sociaal vastgoed hebben gekwalificeerd als vastgoedbelegging waarderen hun sociaal vastgoed tegen actuele waarde (marktwaarde). Opvallend is dat de waarderingsgrondslag historische kostprijs alleen wordt toegepast door woningcorporaties met minder dan 20.000 verhuureenheden. Alle woningcorporaties met meer dan 20.000 verhuureenheden waarderen hun sociaal vastgoed tegen actuele waarde.

In tabel 5 is de gekozen waarderingsgrondslag voor het commercieel vastgoed weergegeven. Zestien woningcorporaties (33\%) waarderen hun commercieel vastgoed op historische kostprijs, 33 woningcorporaties (67\%) op actuele waarde (marktwaarde). Met name de kleinere woningcorporaties passen voor het commercieel vastgoed het kostprijsmodel toe. Alle woningcorporaties die hun sociaal vastgoed tegen historische kostprijs waarderen, passen voor hun commercieel vastgoed eveneens het kostprijsmodel toe. Alle woning- corporaties met meer dan 20.000 verhuureenheden passen het actuele-waardemodel toe en waarderen hun commercieel vastgoed tegen marktwaarde.

\subsection{Kostprijsmodel sociaal en commercieel vastgoed}

\subsubsection{Regelgeving}

Waardering volgens het kostprijsmodel houdt in dat het vastgoed wordt gewaardeerd tegen verkrijgings- of vervaardigingsprijs verminderd met cumulatieve afschrijvingen en bijzondere waardeverminderingen, in overeenstemming met RJ 212 Materiële vaste activa. Woningcorporaties dienen in de toelichting van de jaarrekening de gebruikte afschrijvingsmethoden, de gebruiksduur of de afschrijvingspercentages van elk van de categorieën vastgoed te vermelden (RJ 212.701).

In het verleden waren de rentelasten over de financiering en de afschrijving op het vastgoed bij woningcorporaties vaak aan elkaar gekoppeld. Vastgoed dat werd gefinancierd met annuïtaire leningen werd volgens de annuitaire methode afgeschreven. Volgens de herziene RJ 645 zal het vrijwel nooit meer passend zijn om de annuitaire afschrijvingsmethode te hanteren (Raad voor de Jaarverslaggeving, 2011a). Dit houdt in dat woningcorporaties die de annuitaire afschrijvingsmethode toepasten, in 2012 moeten overgaan op een andere afschrijvingsmethode. De wijziging van de afschrijvingsmethodiek dient te worden verwerkt als een schattingswijziging (RJ 145.101/RJ 940). Dit houdt in dat de wijziging prospectief in de jaarrekening wordt verwerkt.

\section{Tabel 5 Waarderingsgrondslag commercieel vastgoed}

\begin{tabular}{|l|c|c|}
\hline Categorie & Kostprijsmodel & Actuele-waardemodel \\
\hline $1.500-5.000$ & 5 & 4 \\
\hline $5.000-10.000$ & 4 & 6 \\
\hline $10.000-15.000$ & 3 & 7 \\
\hline $15.000-20.000$ & 4 & 6 \\
\hline $20.000+$ & 0 & 10 \\
\hline Totaal & $\mathbf{1 6}$ & $\mathbf{3 3}$ \\
\hline
\end{tabular}


Als de schattingswijziging van belang is, dient de woningcorporatie de aard van de schattingswijziging alsmede het kwantitatieve effect op het boekjaar en toekomstige boekjaren toe te lichten (RJ 145.304/305). Volgens de Handreiking voor het toepassen van RJ 645 (2011) (Werkgroep Jaarverslaggeving Toegelaten Instellingen Volkshuisvesting, 2011) is het aanvaardbaar om alle aanpassingen die voortvloeien uit de gewijzigde RJ 645 integraal als stelselwijziging te verwerken indien deze wijzigingen tegelijkertijd worden doorgevoerd. De Handreiking kiest hiermee voor een praktische benadering die niet geheel in overeenstemming is met de Richtlijnen voor de jaarverslaggeving.

\subsubsection{Empirisch onderzoek}

Veertien (88\%) van de 16 woningcorporaties die hun vastgoed op historische kostprijs waarderen, vermelden de afschrijvingsduur van het vastgoed in de toelichting, twee woningcorporaties (12\%) hebben de afschrijvingsduur niet vermeld (zie tabel 6). Alle zestien woningcorporaties passen de lineaire afschrijvingsmethode toe. In 2012 is er dus geen enkele woningcorporatie meer die de annuiltaire afschrijvingsmethode hanteert. Acht woningcorporaties hebben de afschrijvingsmethode in 2012 gewijzigd ten opzichte van 2011. Van deze acht woningcorporaties hebben zes woningcorporaties (75\%) de wijziging van de afschrijvingsmethode verwerkt als een schattingswijziging. Deze woningcorporaties hebben de aard en het kwantitatieve effect van de schattingswijziging toegelicht. Twee woningcorporaties $(25 \%)$ hebben de wijziging van de afschrijvingsmethode als een stelselwijziging verwerkt in overeenstemming met de Handreiking voor het toepassen van RJ 645 (2011) (Werkgroep Jaarverslaggeving Toegelaten Instellingen Volkshuisvesting, 2011).

\section{Tabel 6 Afschrijvingsmethode}

\begin{tabular}{|c|c|c|c|c|c|c|}
\hline & \multicolumn{5}{|c|}{ Categorie (zie tabel 1) } & \multirow[b]{2}{*}{ totaal } \\
\hline & 1 & 2 & 3 & 4 & 5 & \\
\hline \multicolumn{7}{|c|}{ Afschrijvingsduur vermeld? } \\
\hline $\mathrm{Ja}$ & 5 & 3 & 3 & 3 & 0 & 14 \\
\hline Nee & 0 & 1 & 0 & 1 & 0 & 2 \\
\hline \multicolumn{7}{|c|}{ Is de afschrijvingsmethode in 2012 gewijzigd t.0.v. $2011 ?$} \\
\hline Ja & 0 & 2 & 3 & 3 & 0 & 8 \\
\hline Nee/niet toegelicht & 5 & 2 & 0 & 1 & 0 & 8 \\
\hline \multicolumn{7}{|c|}{ Verwerking wijziging afschrijvingsmethode } \\
\hline Schattingswijziging & 0 & 1 & 2 & 3 & 0 & 6 \\
\hline Stelselwijziging & 0 & 1 & 1 & 0 & 0 & 2 \\
\hline \multicolumn{7}{|c|}{ Aard en het kwantitatieve effect van de schattingswijziging toegelicht? } \\
\hline $\mathrm{Ja}$ & 0 & 1 & 2 & 3 & 0 & 6 \\
\hline Nee & 0 & 0 & 0 & 0 & 0 & 0 \\
\hline
\end{tabular}

\subsection{Actuele-waardemodel sociaal vastgoed gekwalificeerd als bedriffsmiddel}

\subsubsection{Regelgeving}

Een woningcorporatie die haar sociaal vastgoed gekwalificeerd als bedrijfsmiddel tegen actuele waarde waardeert, dient het actuele-waardemodel van RJ 212.403 toe te passen en het vastgoed op bedrijfswaarde te waarderen.

De bedrijfswaarde is de contante waarde van de aan een actief of samenstel van activa toe te rekenen geschatte toekomstige kasstromen die kunnen worden verkregen met de uitoefening van het bedrijf (art. 3 Besluit actuele waarde). De woningcorporatie bepaalt de bedrijfswaarde op het niveau van de kasstroomgenerende eenheid op basis van RJ 121.309 tot en met 327.

De bedrijfswaarde wordt gebaseerd op kasstroomprognoses die de beste schatting van het bestuur van de woningcorporatie weergeven van de economische omstandigheden die van toepassing zullen zijn gedurende de resterende exploitatieduur van het vastgoed. Om de bedrijfswaarde van een complex te bepalen moet het bestuur van de woningcorporatie dus een aantal uitgangspunten en veronderstellingen formuleren. De belangrijkste uitgangspunten en veronderstellingen zijn de exploitatieduur, de jaarlijkse huurontwikkeling, de mutatiegraad, de jaarlijkse lastenontwikkeling, de leegstand en de restwaarde. Als de woningcorporatie het voornemen heeft om complexen te verkopen, zijn ook het verwachte verkooptempo en de verkoopprijzen van belang. Bij het schatten van de bedrijfswaarde dienen kasstroomprognoses voor de eerste vijf jaar gebaseerd te zijn op de goedgekeurde budgetten door het bestuur van de woningcorporatie. De kasstroomprognoses na vijf jaar worden geschat door extrapolatie van de prognoses (RJ 121.310). Gezien de onzekerheid over de toekomstige ontwikkeling van de kasstromen, ligt het voor de hand voor deze jaren aan te sluiten op de door de sectorinstituten vastgestelde percentages (Deloitte, 2012).

De omvang van de bedrijfswaarde wordt in belangrijke mate bepaald door de gehanteerde disconteringsvoet. Volgens RJ 121.323 moet een disconteringsvoet voor belastingen worden gehanteerd die zowel de actuele marktrente als de specifieke risico's met betrekking tot het vastgoed weergeeft. Woningcorporaties hanteren bij het schatten van de bedrijfswaarde veelal de disconteringsvoet die door het Waarborgfonds Sociale Woningbouw (WSW) is vastgesteld (Deloitte, 2012). Het WSW hanteert een disconteringsvoet van $5,25 \%$, bestaande uit de inschatting van de actuele rente op tienjaars staatsleningen van $2,5 \%$, de langetermijninschatting van de inflatie van $2 \%$ en een risico-opslag van $0,75 \%$. 
De woningcorporatie dient voor het sociaal vastgoed gekwalificeerd als bedrijfsmiddel en gewaardeerd op bedrijfswaarde in de toelichting van de jaarrekening uiteen te zetten welke benaderingswijze is toegepast, de aannames waarop de verwachtingen zijn gebaseerd en de gehanteerde disconteringsvoet (RJ 645.505).

De herziene RJ 645 kent ten opzichte van de 'oude' RJ 645 een aantal wijzigingen voor wat betreft het schatten van de omvang van de bedrijfswaarde en het verwerken van de bedrijfswaarde in de jaarrekening. De belangrijkste wijzigingen betreffen:

- Bij het bepalen van de bedrijfswaarde is het vanaf 2012 niet meer toegestaan rekening te houden met de rentabiliteitswaardecorrectie op de leningenportefeuille. De rentabiliteitswaardecorrectie betrof het tijdelijke verschil tussen de contante waarde van de verwachte kasstromen uit hoofde van de leningen en beleggingen en de waardering van deze posten in de balans.

- Bij de waardering van vastgoed tegen bedrijfswaarde dient de woningcorporatie rekening te houden met afschrijvingen in overeenstemming met RJ 212.417. Onder de 'oude' RJ 645 hoefde de woningcorporatie geen rekening te houden met afschrijvingen. De achtergrond van deze wijziging is dat de herziene RJ 645 voor de toepassing van actuele waarde verwijst naar RJ 212 Materiële vaste activa, terwijl de 'oude' RJ 645 rechtstreeks verwees naar RJ 121 Bijzondere waardevermindering van vaste activa.

Wij zijn van mening dat het toepassen van afschrijvingen strijdig is met de uitgangspunten van de bedrijfswaarde. Immers, de bedrijfswaarde is een kasstroomgerelateerd begrip en daarbij passen geen afschrijvingen.

Woningcorporaties dienen bij het bepalen van de kasstroomgenererende eenheden aan te sluiten bij het interne beleid en de bedrijfsvoering van de woningcorporatie. De woningcorporatie dient in de toelichting van de jaarrekening de wijze waarop zij de indeling naar kasstroomgenererende eenheden heeft bepaald ten behoeve van de waardering te beschrijven en te motiveren (RJ 645.503).

Op grond van de herziene RJ 645 is het niet langer verplicht een zogenaamd verloopoverzicht van de bedrijfswaarde op te nemen (model II 'oude' RJ 645). Met dit verloopoverzicht werd inzicht gegeven in de gevolgen van onder andere beleidsaanpassingen door het bestuur van de woningcorporatie op hoogte van de bedrijfswaarde.

Vanaf 2013 moeten woningcorporaties een verhuurderheffing betalen over hun bezit. Met de Wet verhuurderheffing is een heffing geïntroduceerd die zich richt op verhuurders van huurwoningen in de gereguleerde sec- tor, dat wil zeggen woningen waarvan de huur lager is dan de grens voor de huurtoeslag. ${ }^{2}$ De wet vloeit voort uit een pakket maatregelen om de woningmarkt beter te laten functioneren. Met de verhuurderheffing wil het kabinet op de eerste plaats het begrotingstekort terugdringen. De hoogte van de heffing is een aantal keren aangepast. De heffing bedraagt in 2013 in totaal $€ 50$ miljoen en loopt op tot $€ 1.700$ miljoen in 2017 . Ultimo 2012 was alleen de verhuurderheffing voor 2013 in de wet vastgelegd (Ministerie van Wonen en Rijksdienst, Stb. 285). De verhuurderheffing voor 2013 bedraagt 0,014 procent van de WOZ-waarde van de huurwoningen. Voor de jaren 2014 tot en met 2017 is op 17 september 2013 een nieuw wetsvoorstel ingediend. ${ }^{3}$ Woningcorporaties kunnen de gevolgen van de invoering van de verhuurderheffing compenseren door de huren inkomensafhankelijk te verhogen dan wel door besparingen door te voeren op onderhoud en beheerlasten.

De omvang van de bedrijfswaarde ultimo 2012 wordt in belangrijke mate beïnvloed door het al dan niet opnemen van de verhuurderheffing vanaf 2014 in de bedrijfswaarde. De verhuurderheffing over 2013 was reeds in 2012 vastgesteld zodat deze heffing in ieder geval moest worden betrokken bij het bepalen van de bedrijfswaarde. De verhuurderheffing over 2014 tot en met 2017 was echter ultimo 2012 nog niet wettelijk verankerd. Het was waarschijnlijk dat de verhuurderheffing ook voor 2014 tot en met 2017 zou worden ingevoerd, echter het percentage van de verhuurderheffing was nog niet vastgesteld. In februari 2013 is het zogenaamde woonakkoord gesloten tussen de regeringspartijen en de partijen D66, ChristenUnie en de SGP. In het woonakkoord is de hoogte van de verhuurderheffing voor de jaren 2014 tot en met 2017 vastgelegd evenals de effecten voor het huurbeleid. ${ }^{4}$ Het uiteindelijke wetsvoorstel is, zoals hiervoor genoemd, op 17 september 2013 ingediend. Bij woningcorporaties en accountants was onduidelijkheid over de vraag of bij het bepalen van de bedrijfswaarde ultimo 2012 rekening moest worden gehouden met verhuurderheffing en inkomensafhankelijke huurverhogingen over de jaren 2014 tot en met 2017. Ook was onduidelijk of de verhuurderheffing na 2017 zou blijven bestaan of dat de heffing in 2018 weer zou worden afgeschaft. Het inrekenen van de verhuurderheffing 2014 tot en met 2017 leidt tot een aanzienlijk lagere bedrijfswaarde van het vastgoed. Het niet-inrekenen van de verhuurderheffing 2014 tot en met 2017 leidt mogelijk tot een te hoge voorstelling van de bedrijfswaarde. Immers, door het woonakkoord is het niet alleen zeer waarschijnlijk geworden dat woningcorporaties ook in de jaren 2014 tot en met 2017 te maken krijgen met de verhuurderheffing, ook de omvang van de heffing is in het woonakkoord vastgelegd. 
De Nederlandse Beroepsorganisatie voor Accountants (2013) heeft de Raad voor de Jaarverslaggeving verzocht duidelijkheid te verschaffen over de verwerking van de verhuurderheffing in de jaarrekening over 2012.

\section{Tabel 7 Belangrijkste veronderstellingen en uitgangspunten voor de berekening van de bedrijfswaarde}

\begin{tabular}{|c|c|c|c|c|c|c|c|}
\hline \multirow{2}{*}{$\begin{array}{l}\text { Belangrijkste veronderstellin- } \\
\text { gen/uitgangspunten toegelicht? }\end{array}$} & \multicolumn{5}{|c|}{ Categorie } & \multirow[b]{2}{*}{ totaal } & \multirow[b]{2}{*}{$\%$} \\
\hline & 1 & 2 & 3 & 4 & 5 & & \\
\hline \multicolumn{8}{|l|}{ Exploitatieduur } \\
\hline $\mathrm{Ja}$ & 4 & 5 & 6 & 5 & 5 & 25 & $96 \%$ \\
\hline Nee & 1 & 0 & 0 & 0 & 0 & 1 & $4 \%$ \\
\hline \multicolumn{8}{|l|}{ Jaarlifkse huurontwikkeling } \\
\hline $\mathrm{Ja}$ & 5 & 5 & 6 & 5 & 5 & 26 & $100 \%$ \\
\hline Nee & 0 & 0 & 0 & 0 & 0 & 0 & $0 \%$ \\
\hline \multicolumn{8}{|l|}{ Jaarlijkse lastenontwikkeling } \\
\hline $\mathrm{Ja}$ & 5 & 5 & 6 & 5 & 4 & 25 & $96 \%$ \\
\hline Nee & 0 & 0 & 0 & 0 & 1 & 1 & $4 \%$ \\
\hline \multicolumn{8}{|l|}{ Mutatiegraad } \\
\hline $\mathrm{Ja}$ & 4 & 3 & 6 & 5 & 2 & 20 & $77 \%$ \\
\hline Nee & 1 & 2 & 0 & 0 & 3 & 6 & $23 \%$ \\
\hline \multicolumn{8}{|l|}{ Huurderving } \\
\hline $\mathrm{Ja}$ & 5 & 5 & 5 & 5 & 3 & 23 & $88 \%$ \\
\hline Nee & 0 & 0 & 1 & 0 & 2 & 3 & $12 \%$ \\
\hline \multicolumn{8}{|l|}{ Restwaarde } \\
\hline $\mathrm{Ja}$ & 4 & 5 & 6 & 5 & 4 & 24 & $92 \%$ \\
\hline Nee & 1 & 0 & 0 & 0 & 1 & 2 & $8 \%$ \\
\hline \multicolumn{8}{|l|}{ Verkooptempo en verkoopprijzen } \\
\hline $\mathrm{Ja}$ & 1 & 2 & 5 & 5 & 3 & 16 & $62 \%$ \\
\hline Nee & 4 & 3 & 1 & 0 & 2 & 10 & $38 \%$ \\
\hline \multicolumn{8}{|l|}{ Disconteringsvoet } \\
\hline $\mathrm{Ja}$ & 5 & 5 & 6 & 5 & 4 & 25 & $96 \%$ \\
\hline $\mathrm{Nee}$ & 0 & 0 & 0 & 0 & 1 & 1 & $4 \%$ \\
\hline
\end{tabular}

Tabel 8 Toelichting bedrijfswaarde

\begin{tabular}{|c|c|c|c|c|c|c|c|}
\hline & \multicolumn{5}{|c|}{ Categorie } & \multirow[b]{2}{*}{ totaal } & \multirow[b]{2}{*}{$\%$} \\
\hline & 1 & 2 & 3 & 4 & 5 & & \\
\hline \multicolumn{8}{|c|}{$\begin{array}{l}\text { In toelichting is beschreven en gemotiveerd de wijze waarop de indeling in } \\
\text { kasstroomgenererende eenheden (complexen) is bepaald? }\end{array}$} \\
\hline $\mathrm{Ja}$ & 3 & 5 & 3 & 4 & 5 & 20 & $77 \%$ \\
\hline Nee & 2 & 0 & 3 & 1 & 0 & 6 & $23 \%$ \\
\hline \multicolumn{8}{|c|}{$\begin{array}{l}\text { Is vrijwillig (Model } 2 \text { RJ } 645 \text { Oud) een verloopoverzicht van de bedrifiswaarde } \\
\text { opgenomen? }\end{array}$} \\
\hline $\mathrm{Ja}$ & 3 & 0 & 4 & 1 & 5 & 13 & $50 \%$ \\
\hline Nee & 2 & 5 & 2 & 4 & 0 & 13 & $50 \%$ \\
\hline
\end{tabular}

De Raad voor de Jaarverslaggeving (2013) heeft echter geconcludeerd dat bestaande Richtlijnen voor de jaarverslaggeving, in het bijzonder RJ 645 en RJ 121, voldoende aanknopingspunten bieden voor de verwerking van de gevolgen van de verhuurderheffing in de jaarrekening.

\subsubsection{Empirisch onderzoek}

De woningcorporatie dient de belangrijkste aannames en veronderstellingen waarop de bedrijfswaarde is gebaseerd in de toelichting uiteen te zetten. Uit het onderzoek blijkt dat niet in alle gevallen alle belangrijke veronderstellingen worden toegelicht (zie tabel 7). Nagenoeg alle woningcorporaties vermelden de exploitatieduur, de jaarlijkse huur- en lastenontwikkeling, de restwaarde en de disconteringsvoet. Van de 26 woningcorporaties die hun sociaal vastgoed waarderen op basis van het actuele-waardemodel hanteren 24 woningcorporaties (92\%) de door het WSW voorgeschreven disconteringsvoet van 5,25\%. Eén woningcorporatie (4\%) hanteert een afwijkende disconteringsvoet van $4,6 \%$. Deze woningcorporatie heeft de disconteringsvoet vastgesteld op een basis van $5,25 \%$, waarbij een afslag van $0,65 \%$ wordt gehanteerd voor de reeds gecontracteerde financiering ten behoeve van het vastgoed in exploitatie. Eén woningcorporatie (4\%) heeft de disconteringsvoet niet toegelicht. De toelichting van de mutatiegraad en het verkooptempo kan worden verbeterd. $23 \%$ van de woningcorporaties heeft de mutatiegraad niet vermeld en $38 \%$ heeft verzuimd het verkooptempo en de verkoopprijzen te vermelden waarmee rekening is gehouden bij het bepalen van de bedrijfswaarde.

Uit het onderzoek blijkt dat geen van de door ons onderzochte woningcorporaties bij het bepalen van de bedrijfswaarde nog rekening houdt met een rentabiliteitswaardecorrectie op de leningenportefeuille. Alle woningcorporaties houden in 2012 rekening met afschrijvingen op de bedrijfswaarde.

Twintig woningcorporaties (77\%) hebben in de toelichting beschreven en gemotiveerd op welke wijze zij de indeling van het sociaal vastgoed naar kasstroomgenererende eenheden hebben bepaald (zie tabel 8). Bij zes woningcorporaties $(23 \%)$ ontbreekt deze toelichting.

In de jaarrekening 2012 hebben dertien woningcorporaties $(50 \%)$ een verloopoverzicht van de bedrijfswaarde opgenomen in overeenstemming met de 'oude' RJ 645. Alle woningcorporaties met meer dan 20.000 verhuureenheden lichten het verloop van de bedrijfswaarde toe. In figuur 3 is een voorbeeld opgenomen van de mutaties in de bedrijfswaarde in de jaarrekening van Stichting WoonFriesland. 
Figuur 3 Best practice verloopoverzicht bedrijfswaarde sociaal vastgoed in exploitatie. Stichting WoonFriesland, jaarrekening 2012, pp. 68-69

\begin{tabular}{|c|c|}
\hline \multicolumn{2}{|l|}{ Sociaal vastgoed in exploitatie } \\
\hline \multicolumn{2}{|l|}{ Saldo per 31 december 2011} \\
\hline Aanschafwaarde & 1.140 .136 \\
\hline Herwaarderingen & 518.648 \\
\hline Cumulatieve afschrijvingen & -503.005 \\
\hline Boekwaarde & 1.155 .779 \\
\hline \multicolumn{2}{|c|}{$\begin{array}{l}\text { Toelichting opgave bedriffswaarde } 2012 \text { ten opzichte van } \\
\text { opgave vorig verslagjaar }\end{array}$} \\
\hline Totale bedrijfswaarde verslagjaar & 1.155 .779 \\
\hline Totale bedrijfswaarde vorig verslagjaar & 927.459 \\
\hline $\begin{array}{l}\text { Mutatie verslagjaar ten opzichte van vorig } \\
\text { verslagjaar }\end{array}$ & 228.320 \\
\hline \multicolumn{2}{|l|}{ Specificatie verloop/effect per on derdeel: } \\
\hline \multicolumn{2}{|l|}{ Autonome ontwikkeling } \\
\hline vrijval kasstromen & -57.477 \\
\hline effect een jaar opschuiven & 54.633 \\
\hline Subtotaal autonome ontwikkeling & -2.844 \\
\hline \multicolumn{2}{|l|}{ Voorraadmutaties } \\
\hline verbetering & 1.286 \\
\hline verkoop & -15.767 \\
\hline sloop & -53 \\
\hline nieuwbouw & 24.354 \\
\hline NAAR Commercieel vastgoed in exploitatie & -2.101 \\
\hline VAN Commercieel vastgoed in exploitatie & 60 \\
\hline Subtotaal voorraadmutaties & 7.779 \\
\hline \multicolumn{2}{|l|}{ Parameter wijzigingen } \\
\hline levensduur & 101.661 \\
\hline huurstijging & 12.585 \\
\hline inflatie/lastenstijging & 4.544 \\
\hline discontovoet & 623 \\
\hline restwaarde & 5.500 \\
\hline Subtotaal parameterwijzigingen & 124.913 \\
\hline \multicolumn{2}{|l|}{ Niveauwijzigingen } \\
\hline huren & 13.411 \\
\hline onderhoudsuitgaven & 4.035 \\
\hline overige exploitatieuitgaven & 122.659 \\
\hline overig niet gespecif & 1.305 \\
\hline subtotaal niveauwijzigingen & 141.410 \\
\hline Rentabiliteitswaarde correctie & -42.493 \\
\hline Totaal specificatie verloop bedrijfswaarde & 228.320 \\
\hline
\end{tabular}

In tabel 9 is weergegeven of en in hoeverre de onderzochte woningcorporaties in de bedrijfswaarde rekening hebben gehouden met de effecten van de verhuurderheffing en de inkomensafhankelijke huurverhoging. Twintig woningcorporaties $(77 \%)$ houden in de bedrijfswaarde rekening met de verhuurderheffing 2013. Twee woningcorporaties (8\%) houden geen rekening met de verhuurderheffing 2013, vier woningcorporaties $(15 \%)$ hebben niet toegelicht of zij rekening houden met de verhuurderheffing 2013. Uit het onderzoek blijkt dat woningcorporaties in de bedrijfswaarde minder vaak rekening houden met de inkomensafhankelijke huurverhoging 2013 dan met de verhuurderheffing 2013. Slechts zes woningcorporaties (23\%) hebben de inkomensafhankelijke huurverhoging 2013 ingerekend. Zeventien woningcorporaties (65\%) hebben de inkomensafhankelijke huurverhogingen 2013 niet ingerekend. Drie woningcorporaties (12\%) hebben niet toegelicht of zij de inkomensafhankelijke huurverhoging 2013 hebben ingerekend. Voor de jaren na 2013 houden minder woningcorporaties rekening met de verhuurderheffing en inkomensafhankelijke huurverhoging. Vijf woningcorporaties (19\%) hebben de verhuurderheffing na 2013 en de inkomensafhankelijke huurverhoging na 2013 ingerekend in de bedrijfswaarde. De belangrijkste reden hiervoor is dat ultimo 2012 de verhuurderheffing en de inkomensafhankelijke huurverhogingen over de jaren 2014 tot en met 2017 nog niet wettelijk waren verankerd (zie paragraaf 6.3.1).

\section{Tabel 9 Verhuurderheffing en inkomensafhankelijke huurverhoging}

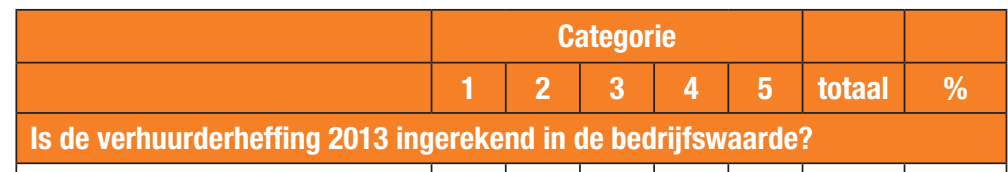

\begin{tabular}{|l|l|l|l|l|l|r|r|}
\hline Ja & 4 & 3 & 5 & 3 & 5 & 20 & $77 \%$ \\
\hline Nee & 1 & 0 & 0 & 1 & 0 & 2 & $8 \%$ \\
\hline Onbekend/niet toegelicht & 0 & 2 & 1 & 1 & 0 & 4 & $15 \%$ \\
\hline
\end{tabular}

Is de verhuurderheffing na 2013 ingerekend in de bedriffswaarde?

\begin{tabular}{|l|r|r|r|r|r|r|r|}
\hline Ja & 1 & 0 & 2 & 0 & 2 & 5 & $19 \%$ \\
\hline Nee & 4 & 3 & 2 & 5 & 2 & 16 & $62 \%$ \\
\hline Onbekend/niet toegelicht & 0 & 2 & 2 & 0 & 1 & 5 & $19 \%$ \\
\hline
\end{tabular}

Heeft de corporatie inkomensafhankelfjke huurverhogingen voor 2013 ingerekend in de bedrifiswaarde?

\begin{tabular}{|l|r|r|r|r|r|r|r|}
\hline Ja & 1 & 0 & 2 & 1 & 2 & 6 & $23 \%$ \\
\hline Nee & 4 & 4 & 4 & 3 & 2 & 17 & $65 \%$ \\
\hline Onbekend/niet toegelicht & 0 & 1 & 0 & 1 & 1 & 3 & $12 \%$ \\
\hline $\begin{array}{l}\text { Heeft de corporatie inkomensafhankeljke huurverhogingen na } 2013 \\
\text { ingerekend in de bedrijfswaarde? }\end{array}$ \\
\hline Ja & 1 & 0 & 2 & 0 & 2 & 5 & $19 \%$ \\
\hline Nee & 4 & 4 & 4 & 4 & 3 & 19 & $73 \%$ \\
\hline Onbekend/niet toegelicht & 0 & 1 & 0 & 1 & 0 & 2 & $8 \%$ \\
\hline
\end{tabular}




\subsection{Actuele-waardemodel sociaal vastgoed gekwalificeerd als vastgoedbelegging}

\subsubsection{Regelgeving}

Sociaal vastgoed gekwalificeerd als vastgoedbelegging wordt bij toepassing van het actuele-waardemodel gewaardeerd tegen marktwaarde overeenkomstig RJ 213 Vastgoedbeleggingen. Voor sociaal vastgoed gekwalificeerd als vastgoedbelegging geldt veelal dat er geen courante prijzen op een actieve markt beschikbaar zijn (RJ 645.209). De woningcorporatie dient de marktwaarde daarom te bepalen op basis van de contante waarde van de geprognotiseerde kasstromen volgens RJ 213.509c. De gebruikelijke methode voor de berekening van de contante waarde van de geprognotiseerde kasstromen is de Discounted Cashflow (DCF)methode.

De in paragraaf 6.3 behandelde bedrijfswaarde wordt gebaseerd op het 'eigen beleid' van de woningcorporatie. De marktwaarde dient de actuele marktsituatie weer te geven op balansdatum en niet op enige datum in het verleden of in de toekomst (RJ 213.507). Dit betekent dat bij de bepaling van de marktwaarde moet worden uitgegaan van per balansdatum lopende huurcontracten met de daaraan verbonden rechten en verplichtingen en van genormeerde jaarlijkse exploitatiekasstromen die op balansdatum zijn afgeleid van marktgegevens. Doordat het vastgoed verhuurd is, wordt de marktwaarde in verhuurde staat vastgesteld.

De marktwaarde in verhuurde staat wordt bepaald op basis van de netto contante waarde van de toekomstige kasstromen. Hierbij kan gebruik worden gemaakt van een rekenmodel, bijvoorbeeld het model dat Investment Property Databank (IPD) beschikbaar stelt ten behoeve van de waardering van IPD aeDex Corporatie Vastgoedindex. De marktwaarde in verhuurde staat geeft het bedrag weer dat het complex bij complexgewijze verkoop naar verwachting zal opbrengen, nadat de verkoper het complex na de beste voorbereiding op de gebruikelijke wijze in de markt heeft aangeboden en waarbij de koper de onroerende zaak aanvaardt onder gestanddoening van de lopende huurcontracten met alle daaraan verbonden rechten en plichten. Om de marktwaarde te bepalen maakt het model gebruik van een nettocontantewaardeberekening waarbij voor een periode van vijftien jaar de verwachte inkomende en uitgaande kasstromen op basis van marktuitgangspunten worden geschat en contant gemaakt. Daarnaast wordt een eindwaarde bepaald aan het einde van de vijftienjaarsperiode aan de hand van een exit yield. Het inschatten van de kasstromen kan volgens twee scenario's plaatsvinden: doorexploiteren en uitponden. Bij het scenario 'doorexploiteren' is de veronderstelling dat het volledige complex in bezit blijft gedurende de volledige rekenperiode. Bij het scenario 'uitponden' is de veronderstelling dat tot verkoop van individuele woningen wordt overgegaan. Bij beide scenario's is het uitgangspunt dat het complex eerst aan een derde wordt verkocht en dat deze de afweging maakt tussen het scenario doorexploiteren of uitponden (Deloitte, 2013).

Woningcorporaties dienen voor het vastgoed gekwalificeerd als vastgoedbelegging en gewaardeerd tegen actuele waarde (marktwaarde) toe te lichten de benaderingswijze voor de marktwaarde, de methoden en relevante veronderstellingen die zijn gehanteerd bij het bepalen van de marktwaarde en de aannames waarop de kasstroomprognoses zijn gebaseerd en de gehanteerde disconteringsvoet (RJ 645.504 en RJ 213.802 sub d). Verder dient de woningcorporatie toe te lichten de mate waarin de marktwaarde van het vastgoed is gebaseerd op een waardering door een onafhankelijke en ter zake kundige taxateur. Indien de waardering niet op deze wijze tot stand gekomen is, dient dit feit toegelicht te worden (RJ 213.802 sub e). De Werkgroep Jaarverslaggeving Toegelaten Instellingen Volkshuisvesting (2011) beveelt aan de getaxeerde waarde van de vastgoedportefeuille in drie jaar integraal door een onafhankelijk en extern taxateur te laten valideren (dit betekent per jaar een derde deel van de vastgoedportefeuille). Het getaxeerde deel van de vastgoedportefeuille dient representatief te zijn voor de totale vastgoedportefeuille, zodat taxaties kunnen worden 'omgeslagen' naar het niet-getaxeerde deel van de vastgoedportefeuille.

\subsubsection{Empirisch onderzoek}

Acht woningcorporaties (waarvan vijf woningcorporaties met meer dan 20.000 verhuureenheden) waarderen het sociaal vastgoed gekwalificeerd als vastgoedbelegging op basis van marktwaarde in verhuurde staat (zie tabel 10). Alle acht woningcorporaties passen de DCFbenadering toe. Van deze acht woningcorporaties hebben zes woningcorporaties (75\%) de gehanteerde disconteringsvoet vermeld. Opvallend is dat twee grote woningcorporaties met meer dan 20.000 verhuureenheden de disconteringsvoet niet hebben vermeld.

Twee woningcorporaties (25\%) hebben de marktwaarde van hun volledig sociaal vastgoed laten vaststellen door een taxateur. Zes woningcorporaties (75\%) vermelden in de toelichting van de jaarrekening dat zij jaarlijks een deel van de marktwaarde van hun sociaal vastgoed door een taxateur laten vaststellen, zodanig dat de marktwaarde elke twee of drie jaar wordt getaxeerd.

Op sociaal vastgoed gekwalificeerd als vastgoedbelegging gewaardeerd tegen marktwaarde mag niet worden afgeschreven. Geen van de onderzochte woningcorporaties schrijft af op de marktwaarde. 


\subsection{Actuele-waardemodel commercieel vastgoed}

\subsubsection{Regelgeving}

Commercieel vastgoed wordt bij toepassing van het actuele-waardemodel gewaardeerd tegen marktwaarde overeenkomstig RJ 213 Vastgoedbeleggingen. Woningcorporaties kunnen de marktwaarde van het commercieel vastgoed het best vaststellen aan de hand van courante prijzen op een actieve markt (indien aanwezig) voor gelijksoortig vastgoed op dezelfde locatie en in dezelfde staat (RJ 213.508). Omdat er vaak geen sprake zal zijn van een actieve markt, kan de marktwaarde worden benaderd op basis van aan de actieve markt voor gelijksoortig vastgoed ontleende bruto-aanvangsrendementen en/of netto-aanvangsrendementen (RJ 213.509a/b). De marktwaarde wordt normaliter vastgesteld door een taxateur. Indien de waardering niet kan worden afgeleid van courante en recente prijzen op de vastgoedmarkt, kan waardering op basis van contante waarde van geprognotiseerde kasstromen plaatsvinden (RJ 213.509c).

Woningcorporaties dienen de methoden, relevante veronderstellingen die zijn gehanteerd bij het bepalen van de marktwaarde en de gehanteerde disconteringsvoet in de toelichting te vermelden (RJ 213.802 sub d). Verder dient de woningcorporatie toe te lichten de mate waarin de marktwaarde van het vastgoed is gebaseerd op een waardering door een onafhankelijke en ter zake kundige taxateur. Indien de waardering niet op deze wijze tot stand gekomen is, dient dit feit te worden toegelicht (RJ 213.802 sub e).

\subsubsection{Empirisch onderzoek}

32 van de 33 woningcorporaties (97\%) die hun commercieel vastgoed op marktwaarde waarderen, hebben de methoden voor het bepalen van de marktwaarde toegelicht (zie tabel 11). Veertien woningcorporaties (44\%) hanteren de DCF-methode en achttien woningcorporaties (56\%) maken gebruik van courante prijzen op een actieve markt.

De marktwaarde van vastgoed is bij zes woningcorporaties (18\%) voor het gehele commerciële vastgoed bepaald door een taxateur. Zeventien woningcorporaties (52\%) vermelden in de toelichting van de jaarrekening dat zij jaarlijks een deel van de marktwaarde van hun commercieel vastgoed door een taxateur laten vaststellen, zodanig dat de marktwaarde van de volledige vastgoedportefeuille elke twee of drie jaar wordt getaxeerd. Eén woningcorporatie (3\%) geeft aan geen gebruik te hebben gemaakt van een taxateur bij het bepalen van de marktwaarde van het commercieel vastgoed. Deze woningcorporatie heeft de marktwaarde bepaald op $65 \%$ van de WOZ-waarde. Negen woningcorporaties (27\%) hebben niet toegelicht of en in welke mate de marktwaarde is vastgesteld door een taxateur.
Tabel 10 Marktwaarde sociaal vastgoed gekwalificeerd als vastgoedbelegging

\begin{tabular}{|c|c|c|c|c|c|c|c|}
\hline & \multicolumn{5}{|c|}{ Categorie } & \multirow[b]{2}{*}{ totaal } & \multirow[b]{2}{*}{$\%$} \\
\hline & 1 & 2 & 3 & 4 & 5 & & \\
\hline \multicolumn{8}{|c|}{ Benaderingswijze voor marktwaarde in de toelichting vermeld? } \\
\hline $\mathrm{Ja}$ & 0 & 1 & 1 & 1 & 5 & 8 & $100 \%$ \\
\hline Nee & 0 & 0 & 0 & 0 & 0 & 0 & $0 \%$ \\
\hline \multicolumn{8}{|c|}{ DCF-methode: is disconteringsvoet vermeld? } \\
\hline $\mathrm{Ja}$ & 0 & 1 & 1 & 1 & 3 & 6 & $75 \%$ \\
\hline Nee & 0 & 0 & 0 & 0 & 2 & 2 & $25 \%$ \\
\hline \multicolumn{8}{|c|}{ Is marktwaarde van sociaal vastgoed vastgesteld door taxateur? } \\
\hline Ja & 0 & 0 & 0 & 0 & 2 & 2 & $25 \%$ \\
\hline Nee & 0 & 0 & 0 & 0 & 0 & 0 & $0 \%$ \\
\hline Roulerend & 0 & 1 & 1 & 1 & 3 & 6 & $75 \%$ \\
\hline
\end{tabular}

Tabel 11 Marktwaarde commercieel vastgoed

\begin{tabular}{|c|c|c|c|c|c|c|c|}
\hline & \multicolumn{5}{|c|}{ Categorie } & \multirow[b]{2}{*}{ totaal } & \multirow[b]{2}{*}{$\%$} \\
\hline & 1 & 2 & 3 & 4 & 5 & & \\
\hline \multicolumn{8}{|c|}{ Benaderingswijze voor marktwaarde in de toelichting vermeld? } \\
\hline $\mathrm{Ja}$ & 4 & 6 & 7 & 6 & 9 & 32 & $97 \%$ \\
\hline Nee & 0 & 0 & 0 & 0 & 1 & 1 & $3 \%$ \\
\hline \multicolumn{8}{|c|}{ Is marktwaarde van commercieel vastgoed vastgesteld door taxateur? } \\
\hline $\mathrm{Ja}$ & 2 & 1 & 0 & 2 & 1 & 6 & $18 \%$ \\
\hline Nee & 0 & 0 & 1 & 0 & 0 & 1 & $3 \%$ \\
\hline Roulerend & 0 & 3 & 5 & 3 & 6 & 17 & $52 \%$ \\
\hline Niet toegelicht & 2 & 2 & 1 & 1 & 3 & 9 & $27 \%$ \\
\hline \multicolumn{8}{|c|}{ Is een verloopoverzicht van de marktwaarde opgenomen? } \\
\hline $\mathrm{Ja}$ & 0 & 1 & 1 & 0 & 2 & 4 & $12 \%$ \\
\hline Nee & 4 & 5 & 6 & 6 & 8 & 29 & $88 \%$ \\
\hline \multicolumn{8}{|c|}{ Invulling actuele waarde commercieel vastgoed } \\
\hline Marktwaarde (DCF-methode) & 2 & 3 & 2 & 1 & 6 & 14 & $44 \%$ \\
\hline Marktwaarde (courante prijzen) & 2 & 3 & 5 & 5 & 3 & 18 & $56 \%$ \\
\hline
\end{tabular}

Op commercieel vastgoed gewaardeerd tegen marktwaarde mag niet worden afgeschreven. Alle woningcorporaties voldoen aan dit voorschrift.

Vier woningcorporaties (12\%) geven inzicht in de waardemutaties van de marktwaarde. Het toelichten van deze mutaties is weliswaar niet verplicht, maar geeft wel inzicht in de effecten die de verschillende parameters en normen hebben op de hoogte van de marktwaarde. In figuur 4 is een voorbeeld van een cijfermatige toelichting van de waardemutatie van de marktwaarde uit de jaarrekening van Stichting Woonbron opgenomen. 


\section{Figuur 4 Best practice verloopoverzicht mutaties marktwaarde. Stichting Woonbron, jaarrekening 2012, p. 30}

\begin{tabular}{|c|c|c|}
\hline \multicolumn{3}{|l|}{ Verloopoverzicht } \\
\hline \multicolumn{3}{|c|}{$\begin{array}{l}\text { Specificatie mutatie reële waarde (bedragen } \\
x € 1.000 \text { ) }\end{array}$} \\
\hline Mutatie algemene marktwaarde & -84.747 & \\
\hline \multicolumn{3}{|c|}{ Mutaties marktbeleid/marktverwachting } \\
\hline Mutatie leegwaarde & -30.641 & \\
\hline Mutatie beklemmingen & 0 & \\
\hline Mutatie mutatiegraden & -13.522 & \\
\hline Mutatie (beheer)kosten & -16.200 & \\
\hline $\begin{array}{l}\text { Mutatie verkoopkosten (incl. } \\
\text { uitpondvergoeding) }\end{array}$ & -1.839 & \\
\hline $\begin{array}{l}\text { Totaal mutatie marktbeleid/ } \\
\text { marktverwachting }\end{array}$ & & -62.203 \\
\hline \multicolumn{3}{|l|}{ Parametermutatie } \\
\hline Mutatie disconteringsvoet & -74.093 & \\
\hline $\begin{array}{l}\text { Mutatie overige parameters (IRS, } \\
\text { inflatie e.d.) }\end{array}$ & 103.974 & \\
\hline Mutatie exit yield & -481 & \\
\hline Mutatie vrije verkoopwaardestijging & -95.884 & \\
\hline Mutatie markthuurstijging & -5.143 & \\
\hline Totaal parametermutatie & & -71.627 \\
\hline \multicolumn{3}{|l|}{ Autonome mutatie } \\
\hline $\begin{array}{l}\text { Mutatie leegstand, huur en } \\
\text { maximaal redelijke huur }\end{array}$ & 49.491 & \\
\hline Mutatie markthuur & 1.544 & \\
\hline Mutatie huurincentive & -1.953 & \\
\hline Totaal autonome mutatie & & 49.082 \\
\hline Mutatie reële waarde & & -84.747 \\
\hline
\end{tabular}

\subsection{Overige toelichtingen}

\subsubsection{Cumulatief bedrag ongerealiseerde waardestijging}

\section{Regelgeving}

In het BBSH is de toepassing van art. 2:390 BW inzake de vorming van een herwaarderingsreserve voor woningcorporaties uitgesloten. Indien woningcorporaties het actuele-waardemodel toepassen voor het sociaal en commercieel vastgoed dienen zij bij het eigen vermogen het cumulatief bedrag aan ongerealiseerde waardestijging bepaald volgens de uitgangspunten van art. 2:390 lid 3 BW (RJ 645.506) toe te lichten.

\section{Empirisch onderzoek}

Uit het onderzoek blijkt dat 31 van de 33 woningcorporaties (94\%) die hun commercieel vastgoed en 23 van de 26 woningcorporaties (88\%) die hun sociaal vastgoed tegen actuele waarde waarderen bij het eigen ver- mogen het cumulatief bedrag aan ongerealiseerde waardestijging hebben vermeld (tabel 12). Met name enkele kleinere woningcorporaties hebben verzuimd het cumulatief bedrag aan ongerealiseerde waardestijging te vermelden.

\subsubsection{Vermelding bedrijfswaarde}

\section{Regelgeving}

Woningcorporaties moeten jaarlijks voor 1 juli ten behoeve van het toezicht informatie verstrekken over de bedrijfswaarde aan het Centraal Fonds Volkshuisvesting. Deze bedrijfswaarde van de onroerende zaken in exploitatie dient te worden bepaald met inachtname van alinea 309 tot en met 327 van hoofdstuk 121 Bijzondere waardevermindering van vaste activa en artikel 7 Besluit actuele waarde en dient te worden opgenomen in de toelichting op de jaarrekening (RJ 645.515).

\section{Empirisch onderzoek}

Uit tabel 13 blijkt dat 35 woningcorporaties (70\%) de bedrijfswaarde van het gehele vastgoed hebben toegelicht. De overige vijftien (30\%) woningcorporaties hebben de bedrijfswaarde niet toegelicht. Met name de toelichting van de bedrijfswaarde van het commercieel vastgoed ontbreekt in enkele gevallen. Dit speelt met name bij woningcorporaties die het sociaal bezit op de bedrijfswaarde waarderen. Van de 26 woningcorporaties die hun sociaal bezit op bedrijfswaarde waarderen, hebben er elf ( $42 \%$ ) geen bedrijfswaarde van het commercieel vastgoed toegelicht. Veertien (54\%) woningcorporaties hebben dit wel toegelicht. Eén woningcorporatie heeft geen commercieel vastgoed.

\section{Conclusies en aanbevelingen}

In dit artikel beschrijven wij de resultaten van het onderzoek naar de wijze waarop woningcorporaties in de jaarrekening 2012 zijn omgegaan met de wijzigingen in de herziene RJ 645 met betrekking tot hun vastgoed in exploitatie. Wij constateren dat een woningcorporatie in haar jaarrekening meerdere waarderingsgrondslagen naast elkaar kan hanteren voor haar vastgoed. Zo kan een woningcorporatie haar sociaal vastgoed waarderen op bedrijfswaarde en haar commercieel vastgoed op marktwaarde. Dit komt de begrijpelijkheid en vergelijkbaarheid van de jaarrekening niet ten goede.

Uit het onderzoek blijkt dat de herziene RJ 645 grote invloed heeft op de omvang van het eigen vermogen van de onderzochte woningcorporaties. Het gemiddeld eigen vermogen primo 2012 is met $81 \%$ toegenomen door rechtstreekse vermogensmutaties als gevolg van stelselwijziging. De belangrijkste reden voor deze stijging van het eigen vermogen is dat een deel van de onderzochte woningcorporaties gebruik heeft gemaakt 
van de mogelijkheid het sociaal vastgoed gekwalificeerd als vastgoedbelegging en het commercieel vastgoed op marktwaarde te waarderen.

Op basis van het onderzoek komen wij tot een aantal aanbevelingen voor woningcorporaties, het Ministerie van Wonen en Rijksdienst en de Raad voor de Jaarverslaggeving.

Voor woningcorporaties die hun vastgoed gekwalificeerd als bedrijfsmiddel tegen bedrijfswaarde waarderen is essentieel dat zij in de toelichting beschrijven en motiveren op welke wijze zij de indeling van hun vastgoed naar kasstroomgenererende eenheden hebben bepaald. Bij ongeveer een kwart van de woningcorporaties ontbreekt deze toelichting. Dit is een belangrijk verbeterpunt. Een ander verbeterpunt heeft betrekking op het toelichten van alle belangrijke veronderstellingen en uitgangspunten voor het bepalen van de bedrijfswaarde, in het bijzonder de uitgangspunten met betrekking tot de mutatiegraad en het verkooptempo en de verkoopprijzen van huurwoningen.

Wij constateren dat woningcorporaties bij het bepalen van de bedrijfswaarde verschillend zijn omgegaan met het al dan niet inrekenen van de verhuurderheffing en de inkomensafhankelijke huurverhoging. Dit komt de vergelijkbaarheid tussen woningcorporaties niet ten goede. Wij adviseren de Raad voor de Jaarverslaggeving voor de jaarrekening 2013 een standpunt in te nemen met betrekking tot het inrekenen van de verhuurderheffing en de inkomensafhankelijke huurverhoging in de bedrijfswaarde teneinde de vergelijkbaarheid van jaarrekeningen te vergroten. Op 17 september 2013 is het wetsvoorstel maatregelen woningmarkt 2014 ingediend. ${ }^{5}$ In dit wetsvoorstel zijn de percentages voor de verhuurderheffing over 2014 tot en met 2017 vastgelegd. In het wetsvoorstel is niet opgenomen of de verhuurderheffing ook na 2017 van toepassing blijft. De inkomensafhankelijke huurverhogingen zijn inmiddels wettelijk verankerd in de Uitvoeringswet huurprijzen woonruimte. Volgens RJ 121.310 dienen kasstroomprognoses gebaseerd te zijn op de meest recente budgetten die zijn goedgekeurd door het bestuur. Prognoses gebaseerd op deze budgetten dienen een periode te bestrijken van maximaal vijf jaar, behalve wanneer een langere periode kan worden gerechtvaardigd. Kasstroomprognoses na deze periode dienen te worden geschat door extrapolatie. Wij zijn van mening dat in ieder geval met de verhuurderheffing en inkomensafhankelijke huurverhogingen over 2014 tot en met 2017 rekening moet worden gehouden bij het bepalen van de bedrijfswaarde van het vastgoed ultimo 2013. Voor wat betreft de verhuurderheffing na 2017 bestaat onduidelijkheid, maar het lijkt dat deze ook na 2017 zal blijven bestaan. Wij dringen aan op een standpunt over het al dan niet
Tabel 12 Toelichting cumulatieve bedrag aan ongerealiseerde waardestijging

\begin{tabular}{|l|r|r|r|r|r|r|r|r|r|}
\hline & \multicolumn{7}{|c|}{ Categorie } & & \\
\hline $\begin{array}{l}\text { Cumulatieve bedrag aan } \\
\text { ongerealiseerde waardestijging }\end{array}$ & 1 & 2 & 3 & 4 & 5 & totaal & $\%$ \\
\hline Commercieel vastgoed & 3 & 5 & 7 & 6 & 10 & 31 & $94 \%$ \\
\hline Ja & 1 & 1 & 0 & 0 & 0 & 2 & $6 \%$ \\
\hline Nee & 3 & 4 & 6 & 5 & 5 & 23 & $88 \%$ \\
\hline Sociaal vastgoed & 2 & 1 & 0 & 0 & 0 & 3 & $12 \%$ \\
\hline Ja &
\end{tabular}

\section{Tabel 13 Toelichting bedrijfswaarde}

\begin{tabular}{|c|c|c|c|c|c|c|c|}
\hline & \multicolumn{5}{|c|}{ Categorie } & \multirow[b]{2}{*}{ totaal } & \multirow[b]{2}{*}{$\%$} \\
\hline & 1 & 2 & 3 & 4 & 5 & & \\
\hline \multicolumn{8}{|c|}{ Bedriffswaarde van het gehele vastgoed in toelichting vermeld? } \\
\hline $\mathrm{Ja}$ & 5 & 6 & 6 & 9 & 9 & 35 & $70 \%$ \\
\hline Nee & 5 & 4 & 4 & 1 & 1 & 15 & $30 \%$ \\
\hline
\end{tabular}

inrekenen van de verhuurderheffing 2014 tot en met 2017 en over de jaren na 2017 teneinde de vergelijkbaarheid van jaarrekeningen te bevorderen.

Verder adviseren wij de Raad voor de Jaarverslaggeving de verplichting om af te schrijven op de bedrijfswaarde te heroverwegen. Wij zijn van mening dat afschrijvingen niet passen bij de bedrijfswaarde daar de bedrijfswaarde een kasstroomgerelateerd waardebegrip is.

Met betrekking tot commercieel vastgoed dat wordt gewaardeerd tegen marktwaarde blijkt uit het onderzoek dat $27 \%$ van de woningcorporaties niet toelicht of en in welke mate de marktwaarde door een taxateur is bepaald. Deze toelichting is nodig om de gebruiker van de jaarrekening inzicht te geven in de kwaliteit van de marktwaarde van het vastgoed. Wij adviseren woningcorporaties in de jaarrekening 2013 deze toelichting op te nemen. Eén woningcorporatie heeft de marktwaarde bepaald als een afgeleide van de WOZwaarde. Wij zijn van mening dat dit een onjuiste invulling is van het begrip marktwaarde en strijdig is met de uitgangspunten van het Besluit actuele waarde.

Bij waardering van vastgoed tegen bedrijfswaarde of marktwaarde is het voor de gebruiker van de jaarrekening van belang inzicht te krijgen in de bestanddelen van de mutatie in de bedrijfswaarde of de marktwaarde. Wij adviseren woningcorporaties een dergelijk overzicht op te nemen zodat de gebruiker inzicht krijgt in de effecten die de verschillende parameters en uit- 
gangspunten hebben op de hoogte van de bedrijfswaarde en de marktwaarde. Wij geven de Raad voor de Jaarverslaggeving in overweging een dergelijk overzicht voor te schrijven.

Tot slot geven wij de minister van Wonen en Rijksdienst in overweging om art. 2:390 BW inzake de herwaarderingsreserve weer van toepassing te verklaren op woningcorporaties. Hoewel woningcorporaties worden gedreven in de rechtsvorm van een stichting of vereniging en een herwaarderingsreserve uit het oogpunt van kapitaalbescherming niet nodig is, zijn wij van mening dat de herwaarderingsreserve wel van belang is voor woningcorporaties. Doordat waardemutaties in de marktwaarde rechtstreeks in het resultaat worden verwerkt, bestaat het resultaat en het eigen vermogen voor een substantieel deel uit ongerealiseerde waardestijgingen van het vastgoed. Omdat voor het vastgoed geen frequente marktnoteringen bestaan, is van belang om door middel van de herwaarderingsreserve toe te lichten welk deel van het eigen vermogen nog niet gerealiseerd is.

E.J.N. Jungheim MSc is werkzaam als manager bij Deloitte Accountants BV in de auditpraktijk Public Sector. Daarnaast is hij verbonden aan het vaktechnisch bureau Accounting \& Auditing Center van Deloitte. Deze bijdrage is geschreven op persoonlijke titel.

Drs. C.L. Suurland RA is werkzaam als senior manager bij Bureau Vaktechniek Accountants van Baker Tilly Berk NV. Zij is lid van de vaktechnische staf van de Raad voor de Jaarverslaggeving en als zodanig betrokken bij de RJwerkgroep Toegelaten instellingen volkshuisvesting. Deze bijdrage is geschreven op persoonlijke titel.

De auteurs danken Miran Khidir voor zijn waardevolle bijdrage aan het empirisch onderzoek.

\section{Noten}

Woningcorporaties moeten ook aan hun volkshuisvestelijke taken voldoen. Een woningcorporatie die het sociaal vastgoed kwalificeert als vastgoedbelegging, streeft naar een gegeven de omstandigheden zo optimaal mogelijk rende- ment. Dit rendement zal evenwel, gezien de volkshuisvestelijke taken van woningcorporaties, lager zijn dan het rendement van een commerciele vastgoedbelegger.

2. Stb. 2013, 285
Kamerstukken II 2013/14, 33756, nr. 2.

Kamerstukken II 2009/10, 32847, nr. 12.

Kamerstukken II 2013/14, 33756, nr. 2.

\section{Literatuur}

- Centraal Fonds Volkshuisvesting (2012). Corporatie in perspectief 2012. Geraadpleegd op http://www.cfv.nl/cfvpublicaties/publicatie/ Corporatie_in_Perspectief_2012.

- Deloitte (2013). Notities bij implementatie RJ 645: Marktwaarde en bedrijfswaarde. Geraadpleegd op: https://www.woconet.n/getattachment/Delen/Best-practices/verslaggeving/ Notities-bii-implementatie-RJ-645--Marktwaarde-en-/Notities-bii-implementatie-RJ645-Marktwaarde-en-bedrijfswaarde.pdf. aspx.

- Deloitte (2012). Handboek Woningcorporaties 2012. Een handreiking voor de praktijk. Deventer: Kluwer.

- Deloitte (2011). Richtlijn 645, een vernieuwde verantwoording voor woningcorporaties. Geraadpleegd op http://www.deloitte.com/assets/Dcom-Netherlands/Local\%2OAssets/ Documents/NL/Branches/Publieke\%20Zaken/ nl_nl_ps_richtlijn_645-LR.pdf.

- European Commission (2009). State aid No E
2/2005 and N 642/2009 - The Netherlands existing and special project aid to housing corporations. Geraadpleegd op http://ec.europa.eu/eu_law/state_aids/comp-2009/n64209.pdf.

- Ministerie van Wonen en Rijksdienst (2013). Wet verhuurderheffing (Staatsblad 285). Geraadpleegd op http://www.eerstekamer.n// wetsvoorstel/33407_wet_verhuurderheffing.

- Nederlandse Beroepsorganisatie voor Accountants (NBA) (2012). Brief aan Raad voor de Jaarverslaggeving inzake verhuurderheffing woningcorporaties. Geraadpleegd op http:// www.nba.n//Documents/Naktechnisch-thema/ externe-verslaggeving/2013/130409\%20 Final\%20\%20Brief\%20en\%20bilage\%20 inzake\%20Verhuurderheffing\%20woningcorporaties\%202.pdf.

- Raad voor de Jaarverslaggeving (RJ) (2013). Brief aan NBA inzake verzoek NBA inzake wetsvoorstel verhuurderheffing. Geraadpleegd op http://www.rjnet.n//Documents/Overi-
ge\%2Opublicaties/Reactie\%20RJ\%20op\%20 verzoek\%20NBA\%20d.d.\%20april\%202013. pdf.

- Raad voor de Jaarverslaggeving (RJ) (2011a). RJ-Uiting 2011-2: 'Richtlijn 645 toegelaten instellingen volkshuisvesting (herzien 2011)'. Geraadpleegd op http://www.rjnet.n//Databank/RJ-Uitingen.

- Raad voor de Jaarverslaggeving (RJ) (2011b). Richtlijnen voor de jaarverslaggeving - Jaareditie 2011. Deventer: Kluwer.

- Raad voor de Jaarverslaggeving (RJ) (2010). Richtlijnen voor de jaarverslaggeving- Jaareditie 2010. Deventer: Kluwer.

- Werkgroep Jaarverslaggeving Toegelaten Instellingen Volkshuisvesting (2011). Handreiking voor het toepassen van RJ 645 (2011). Geraadpleegd op https://www.woconet.nl/ wokoportal/media/WocoMediaLibrary/verslaggeving_handreiking-ri645-31-januari-2012. pdf. 


\section{Bijlage 10nderzoekspopulatie}

\begin{tabular}{|c|c|c|}
\hline Nr. & Naam & $\begin{array}{l}\text { Verhuur- } \\
\text { eenheden }\end{array}$ \\
\hline \multicolumn{3}{|c|}{ Categorie 1 (1.500 - 5.000 verhuureenheden) } \\
\hline 1 & Woningstichting De Volmacht & 1.667 \\
\hline 2 & Woningstichting Volksbelang & 1.988 \\
\hline 3 & Rhenense Woningstichting & 2.272 \\
\hline 4 & Woningstichting Laarbeek & 2.344 \\
\hline 5 & Woningstichting de Wieren & 2.767 \\
\hline 6 & Stichting Rondom Wonen & 3.289 \\
\hline 7 & Woningstichting Beter Wonen Vechtdal & 3.520 \\
\hline 8 & Bouwvereniging Woningbelang & 3.759 \\
\hline 9 & Stichting 3B Wonen & 4.127 \\
\hline 10 & Stichting WBO Wonen & 4.648 \\
\hline \multicolumn{3}{|c|}{ Categorie 2 (5.000 - 10.000 verhuureenheden) } \\
\hline 11 & Woonstichting SSW & 5.298 \\
\hline 12 & Stichting de Woonschakel Westfriesland & 5.817 \\
\hline 13 & Woningstichting de Veste & 6.342 \\
\hline 14 & Stichting Woongoed Zeeuws-Vlaanderen & 6.346 \\
\hline 15 & stichting WoonOpMaat & 6.976 \\
\hline 16 & Stichting Rijswijk Wonen & 7.048 \\
\hline 17 & Woningbouwvereniging de Sleutels & 7.898 \\
\hline 18 & Casade Woonstichting & 9.070 \\
\hline 19 & Stichting Woonpartners & 9.118 \\
\hline 20 & Stichting Woonvisie & 9.513 \\
\hline \multicolumn{3}{|c|}{ Categorie 3 (10.000 - 15.000 verhuureenheden) } \\
\hline 21 & Woonstichting Leystromen & 10.397 \\
\hline 22 & Stichting HW Wonen & 10.547 \\
\hline 23 & Stichting Woonkracht10 & 11.587 \\
\hline 24 & Stichting KleurrijkWonen & 11.767 \\
\hline 25 & Stichting Waterweg Wonen & 12.002 \\
\hline 26 & Stichting GroenWest & 12.168 \\
\hline 27 & Stichting Acantus Groep & 13.460 \\
\hline 28 & Stichting Volkshuisvesting Arnhem & 13.498 \\
\hline 29 & Stichting Volkshuisvestingsgroep Wooncompagnie & 13.501 \\
\hline 30 & Stichting Thuisvester & 14.546 \\
\hline
\end{tabular}

\begin{tabular}{|l|l|l|}
\hline Nr. & Naam & Verhuur- \\
\hline
\end{tabular} eenheden

Categorie 4 (15.000 - 20.000 verhuureenheden)

\begin{tabular}{r|l|r|}
\hline 31 & Stichting Woonwaard Noord-Kennemerland & 15.045 \\
\hline 32 & Stichting DUW0 & 15.645 \\
\hline 33 & Stichting Talis & 15.799 \\
\hline 34 & Stichting Wonen Zuid & 16.285 \\
\hline 35 & Stichting Woonbedrijf ieder1 & 16.605 \\
\hline 36 & Woningstichting Domijn & 16.958 \\
\hline 37 & Stichting Accolade & 17.293 \\
\hline 38 & Stichting Parteon & 17.902 \\
\hline 39 & Stichting De Woonplaats & 18.437 \\
\hline 40 & Stichting Elkien & 18.739 \\
\hline
\end{tabular}

Categorie $\mathbf{5}$ (20.000 + verhuureenheden)

\begin{tabular}{r|l|r|}
\hline 41 & Stichting WoonFriesland & 22.563 \\
\hline 42 & Stichting Wonen Limburg & 25.690 \\
\hline 43 & Stichting Mooiland & 28.846 \\
\hline 44 & Stichting WonenBreburg & 29.890 \\
\hline 45 & Stichting Lefier & 33.461 \\
\hline 46 & Stichting Staedion & 37.426 \\
\hline 47 & Woningstichting Rochdale & 44.847 \\
\hline 48 & Stichting Woonzorg Nederland & 47.187 \\
\hline 49 & Stichting Woonbron & 49.407 \\
\hline 50 & Stichting Havensteder & 50.164 \\
\hline
\end{tabular}

